\title{
THE STRUCTURE OF MORAINES IN LYNGSDALEN, NORTH NORWAY
}

\author{
By R. W. Galloway \\ (Department of Geography, Edinburgh University)
}

\begin{abstract}
The structure of some moraines in and around two glaciers in northern Norway was studied by the ABSTRACT. The structure of some moraines in and around two glaciers in the parallel to the direction of movement of
method of fabric analysis. It was found that englacial material tends to lie partions method of fabric analy in lateral and terminal moraines shows orientations which appear to be related to the conditions under which it was deposited.

RÉsumé. On a étudié la structure de quelques moraines de deux glaciers en Norvège septentrionale par la méthode

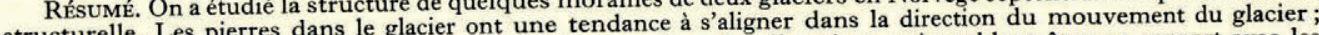
structurelle. Les dans les moraines latérales et frontales s'alignent dans des directions qui semblent être en rapport avec les conditions dans lesquelles la glace les avait déposées.
\end{abstract}

\section{INTRODUCTION}

Fabric analyses, or the study of preferred orientations of stones in glacial and other superficial deposits has attracted increasing attention in recent years, following the pioneer work of K. Richter ${ }^{4,5}$ and Holmes ${ }^{1}$. Fabric analysis has been frequently used in the study of Pleistocene glacial deposits, but studies in and around present day glaciers are rare.

The studies discussed here were carried out as part of the work of an expedition from Edinburgh University to Lyngenhalvöya in north Norway on moraines in Övre Lyngsdalen a ro km.-long valley that descends eastward from the Jiek'kevarri massif to the fjord, Lyngen. (Fig. I, p. 73r.) Here lie two valley glaciers, Lyngsdalsbreen and Litle Jiek'kevarribreen, both largely maintained by avalanches from ice caps on the surrounding plateaux, and both terminating at an altitude of about $400 \mathrm{~m}$. The former has a fairly smooth gradient, the latter ends in an ice fall. Both have retreated several hundred metres from prominent moraines that mark the limit of a considerable re-advance and which in places overlie an older set of moraines. (Fig. 2, p. 73I.) In both cases, the portion of the morainic arc lying on the right hand side of the snout and outwash streams is larger $\left(5^{-2} 5 \mathrm{~m}\right.$. high), with a more mixed constitution than the block moraine (c. $2 \mathrm{~m}$. high) resting on the opposite side of the valley. The inner face of the Litle Jiek'kevarribre moraine is fresh and so steep that all loose debris falls clear and does not mask the structure.

\section{Method}

When making a fabric analysis, the bearing of the long axes of at least 50 stones about $10 \mathrm{~cm}$. long was measured by compass. Only stones with a clearly defined long axis dipping at less than 45 degrees were chosen, and each sample of stones was gathered from as small an area as possible to minimize the risk of errors caused by unconscious selection of stones lying in a certain direction. It is obvious that the sample taken should be truly typical of the deposit being investigated. The readings were assembled into ten degree groups: $0-10,1 \mathrm{I}-20,2 \mathrm{I}-3 \mathrm{O}$, etc. and plotted on a rose diagram. (Fig. 3, p. 731.) In most cases a clearly defined maximum appeared, representing the preferred orientation of the stones. This maximum has been shown to be generally parallel to the direction of movement of the glacier but in some cases may be transverse to it 1, 4, 5 .

In Fig. 2 the preferred orientation at a particular point on the moraine has been plotted as an arrow pointing in the appropriate direction, its length being proportional to the percentage of stones in the largest ten degree group. Where two fabric analyses were made at the same point in the section but at ${ }^{2}$ different depths, the lower analysis is indicated by a double stroke across the tail of the arrow. Care was taken to ensure that the analyses were made at points where sliding and rolling of the stones since deposition by the ice had not occurred. 

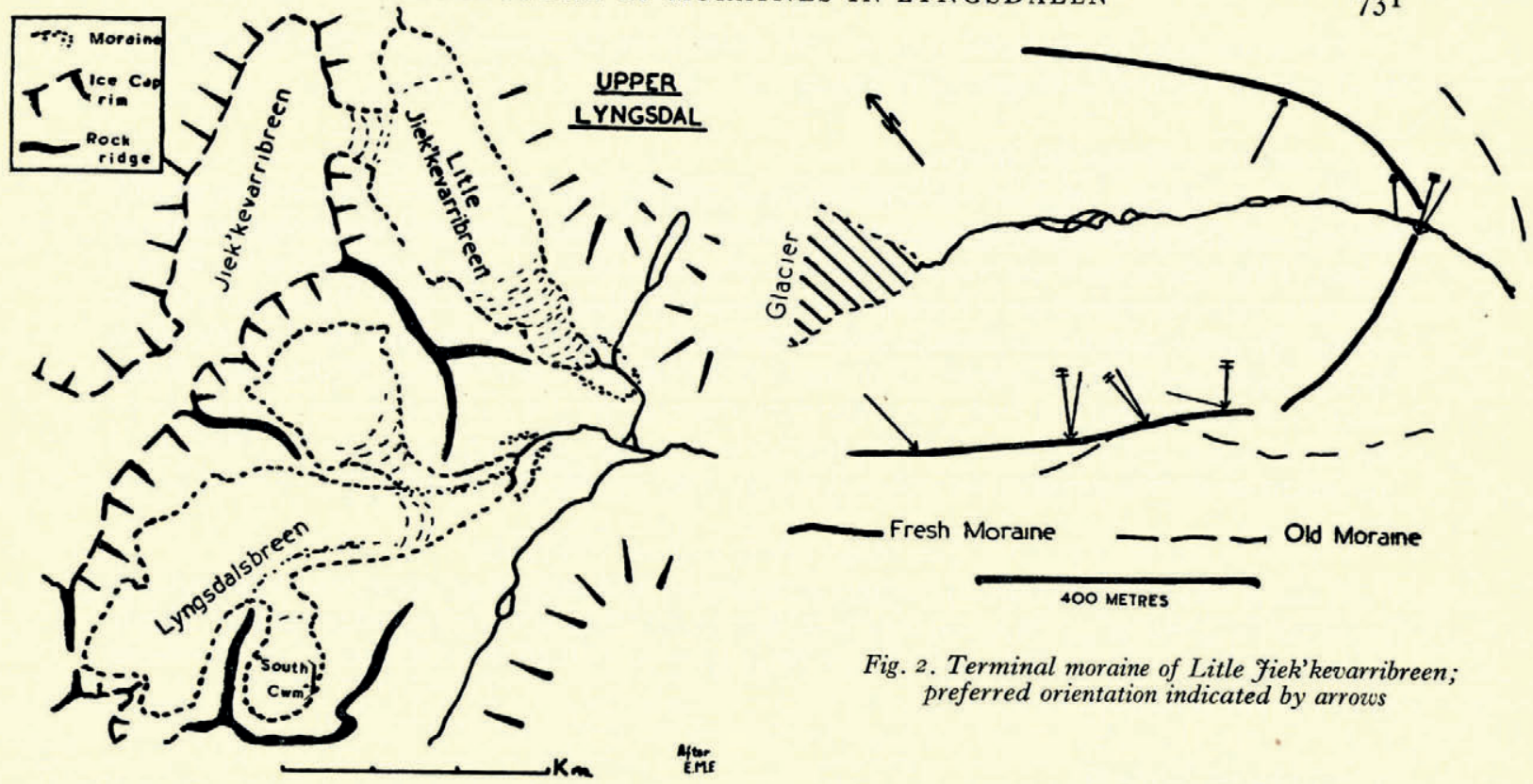

Fig. 2. Terminal moraine of Litle Fiek'kevarribreen; preferred orientation indicated by arrows

Fig. I. Lyngsdalen and its glaciers. The "North Cwm" is the tributary glacier situated to the north of the "South Cwm"

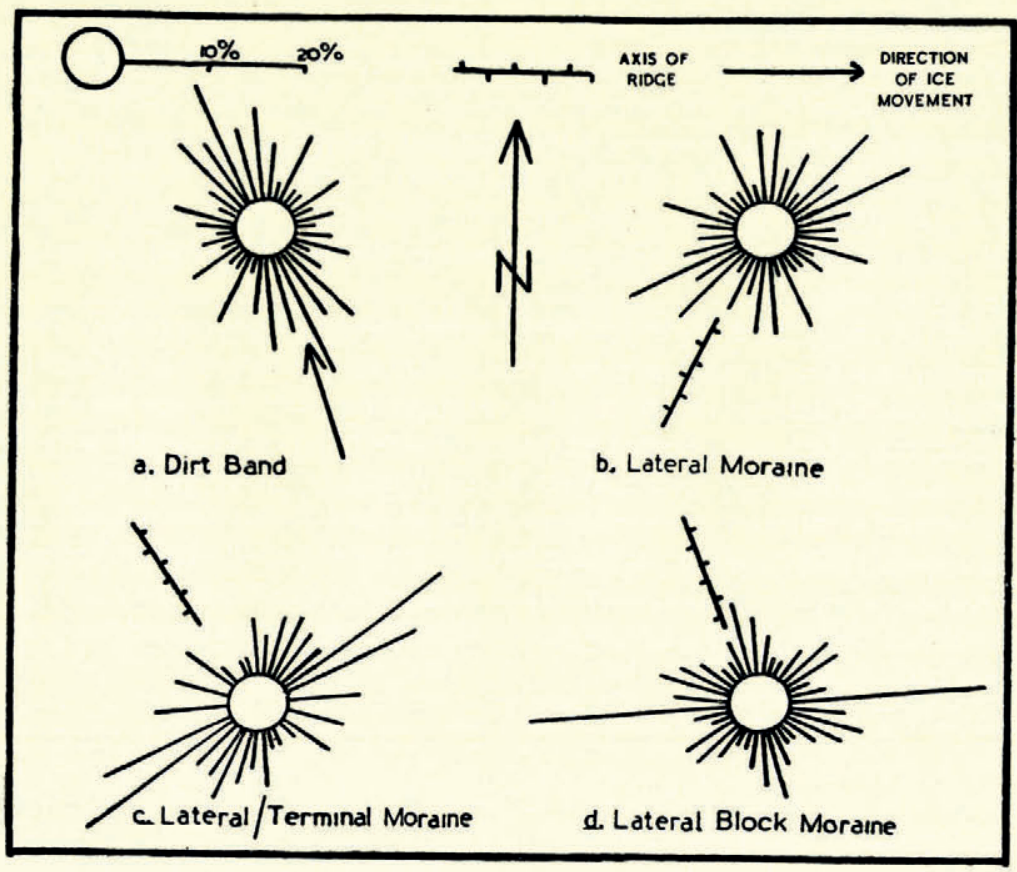

Fig. 3. Rose diagrams of fabric analyses 
The orientation of englacial material was studied on Lyngsdalsbreen while the moraines studied were those of Litle Jiek'kevarribreen.

\section{Orientation of Englacial Material}

Wherever ablation revealed englacial moraines, whether lateral or medial, it was obvious that the stones had been generally lying in the ice with their long axes parallel to the movement of the glacier. This orientation is certainly due to dynamic forces related to the movement of the ice and contrasts with the orientation of stones in a stream bed which tend to lie at right angles to the current. In some cases the orientation may correspond to the original attitude in which the stone became incorporated in the glacier: at the head of the "South Cwm" branch of the glacier it was noted how blocks detached from the rock walls above adopted a sliding position, aligned down the slope, when they came to rest on the firn surface. In this attitude, parallel to the direction of movement of the firn towards the exit of the cwm, they would be eventually carried down to the main glacier.

Only one dirt band suitable for making fabric analyses was found.

It was a lens of stony material reaching a maximum thickness of $50 \mathrm{~cm}$. of which the outcrop appeared for about $50 \mathrm{~m}$. on a sloping ice surface in the "North Cwm" tributary glacier. Fabric analysis showed a majority of stones in the band lying parallel to the direction of ice movement at this point. (Fig. 3a.)

\section{Structure of Moraines}

Fabric analyses made on the steep inner face of the lateral part of the Litle Jiek'kevarribre morainic arc at two levels (c. 3 and ro $\mathrm{m}$. below the crest) showed clear preferred orientations transverse to the axis of the ridge, usually with a forward-pointing component. (Figs. 2 and $3 \mathrm{~b}, 3 \mathrm{c}$.) This transverse orientation was apparent to even a casual inspection and may be observed in Fig. 4 (p. 763). Since stones are generally transported by the ice in an attitude parallel to its direction of motion, this transverse orientation implies that the ice was moving radially in the tongue when the moraine was built.

Where the moraine swung from the lateral to the terminal position, the preferred orientation changed and became parallel to the axis of the ridge. This suggests that the terminal portion of the moraine was built up by a process of thrusting and rolling in contrast to the lodgement that built the lateral part. Similar preferred orientations were noted in the block moraine on the other side of the outwash stream. In the lateral part, the blocks lay transversely to the ridge, with a slight forward-pointing component (Fig. 3 d), while in the terminal part the stones lay approximately parallel to the ridge.

Nowhere did the upper and lower preferred orientations coincide exactly. This suggests that either 50 measurements were insufficient to give an accurate picture of the orientation, or that the structure of the moraine varied with depth. At close quarters no stratification could be discerned on the steep face, but when seen from a distance of about half a kilometre sub-horizontal, subparallel layers could be detected, some layers being distinctly richer in boulders than others. A detailed study of such a moraine with analyses made at close intervals vertically and horizontally might yield interesting information on variations in the moraine-building forces. The existence of important variations in orientation with depth means that great caution must be used in interpreting the results of fabric analyses from shallow sections in morainic ridges, even if the stones investigated are truly in situ.

\section{Conclusions}

(a) Stones in the englacial, lateral and terminal moraines studied show distinct preferred orientations ascertainable by fabric analyses.

(b) Englacial stones tend to lie parallel to the movement of the ice in the glaciers discussed here. 
(c) In the lateral part of the morainic arc, the stones lie transverse to the ridge, suggesting that radial movements were strong when the moraine was formed.

(d) In the terminal part of the moraine, stones lie parallel to the ridge, suggesting accumulation by rolling and thrusting.

(e) The preferred orientation varies with depth, so that great caution is needed in interpreting results from shallow sections.

\title{
ACKNOWLEDGEMENTS
}

I would like to thank the following for invaluable advice and suggestions in connection with the preparation of the work discussed in this paper: Professors A. Cailleux, R. Miller, H. Poser, J. Tricart and Dr. R. Common.

MS. received 2 May 1955

\section{R E F E R E N C E S}

1. Holmes, C. D. Till fabric. Bulletin of the Geological Society of America, Vol. 52, 1941, p. 1299-354.

2. Hoppe, G. Hummocky moraine regions with special reference to the interior of Norrbotten. Geografiska Annaler, Arg. 34, Ht. I-2, 1952, p. I-7I.

3. Poser, H., and Hövermann, J. Untersuchungen zur Pleistozänen Harz-Vergletscherung. Abhandlungen der Braunschweigischer Wissenschaftlichen Gesellschaft, Bd. 3, 195 I, p. 61-1 5 .

4. Richter, K. Gefüge und Zusammensetzung des norddeutschen Jungmoränengebiets. Abhandlungen aus dem Geologischen-Palaeontologischen Institut der Universität Greifswald, Bd. 11,1933, p. 7-6r.

5. - Gefügestudien im Engebrae, Fondalsbrae und ihren Vorlandsedimenten. Zeitschrift für Gletscherkunde, Bd. 24,1936, p. 22-30.

\section{A NOTE ON SNOW CRYSTAL TYPES IN THE FALKLAND IS LANDS DEPENDENCIES}

\author{
By J. H. Chaplin \\ (Meteorological Office, Livingstone, Northern Rhodesia)
}

DuRING a two year tour of duty with the Falkland Islands Dependencies Survey, I was able to make a visual study of snow-crystal types at two bases. These bases were at Admiralty Bay, South Shetlands (lat. $63^{\circ}$ S., long. $5^{\circ}$ W.), and Port Lockroy, Graham Land (lat. $65^{\circ}$ S., long. $63^{\circ}$ W.). The observations were made between 6 February and 30 November 1949 at the former, and between 3 February 1950 and 25 January $195^{I}$ at the latter. The Admiralty Bay notes are complete, but unfortunately shipped seas aboard the s.v. Fohn Biscoe, flooded, and made illegible, the March I950 notes and the March, May, June, weather notes for Port Lockroy.

Every endeavour was made to study each fall of snow during waking hours. At Admiralty Bay the base hut was submerged by snow during the Spring, hence the actual passage of weather systems was less easily observable and as a result the crystal type/weather analysis is not so full. Also for each station the exact weather pattern was not always clear.

The somewhat longer snow crystal classification used at the bases has been shortened to fit the tentative nomenclature chosen by the Commission on Snow and Ice ${ }^{1}$. Three types outside this were noted, and have been indicated in the accompanying tables by letters. $\mathrm{X}$ is Diamond Dust, which, at Admiralty Bay, gave a magnificent halo display. $\mathrm{Y}$ is a sort of spineless Type 5 , perhaps akin to Shackleton's "sago-snow" 2.

The tables have been prepared on a basis of percentage distribution. In the temperature classification an entry opposite $-3^{\circ}$ would refer to an observation when the Stevenson screen temperature was between $-2^{\circ}$ and $-3.9^{\circ} \mathrm{C}$. I fully realize that the screen temperature may not 


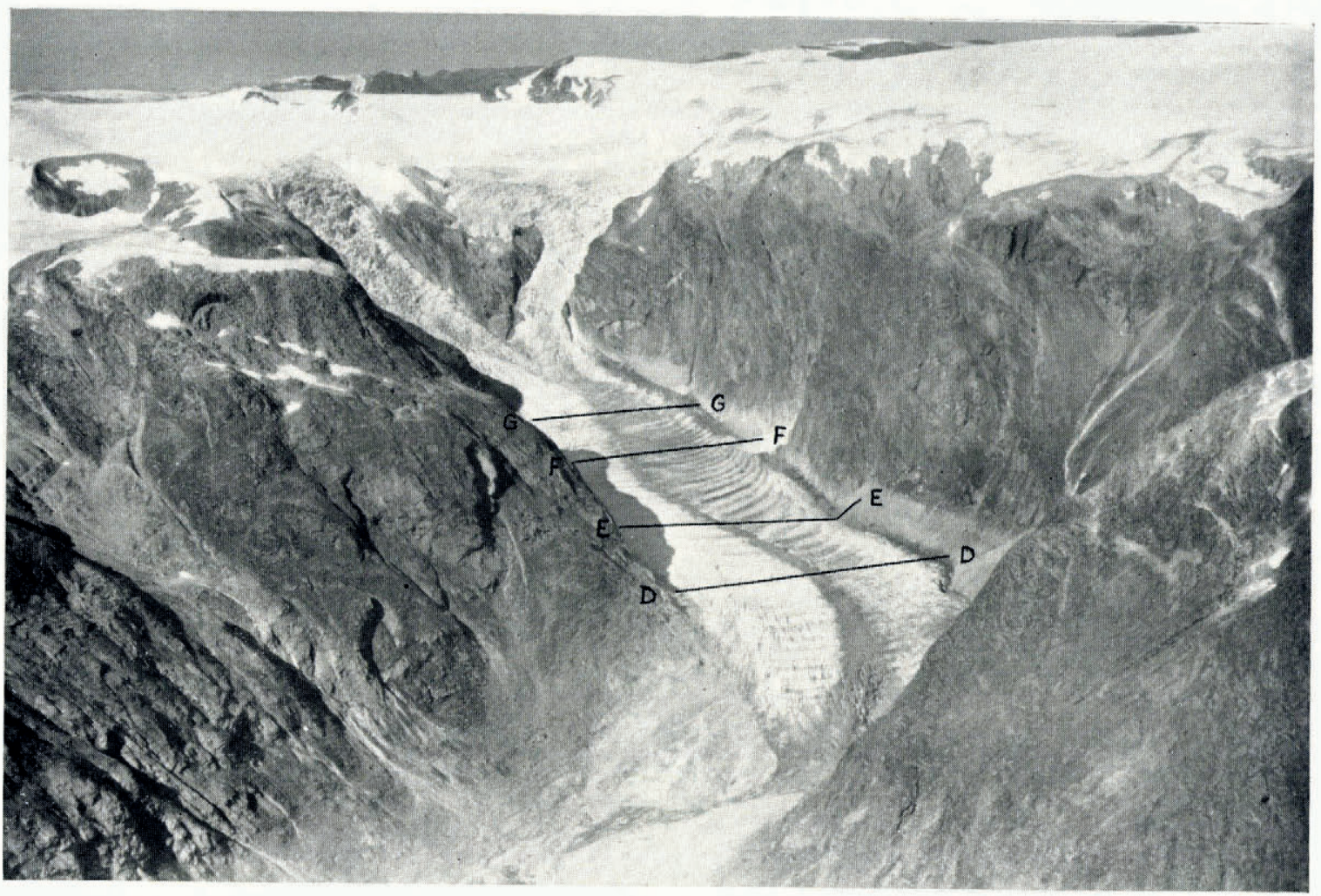

Fig. 6. Air photograph of Austerdalsbreen, showing the form of the valley, and the approximate positions of profiles $D, E, F$ and $G$

Photograph by Wideroe's Flyveselskap og Polarfly A S, Oslo

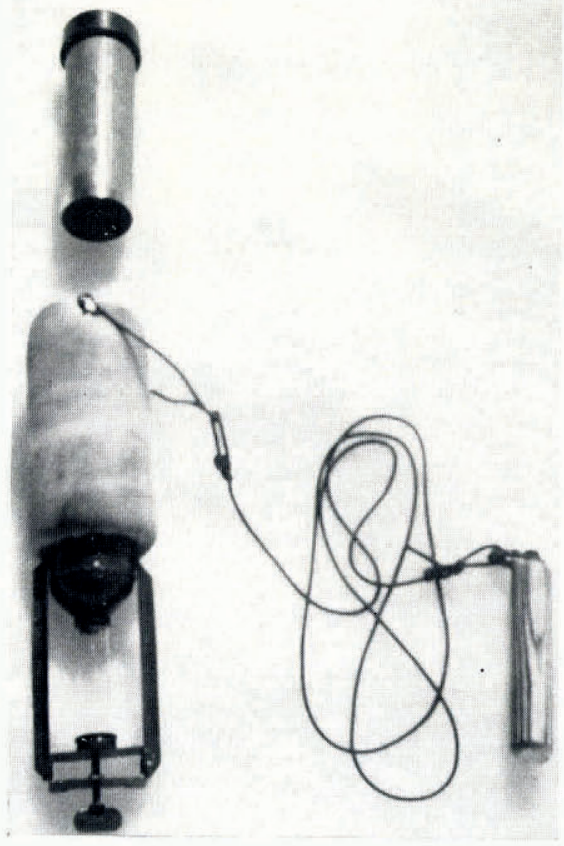

Fig. I. Centrifuge for separating water from melting snow (see E. R. LaChapelle, p.769)

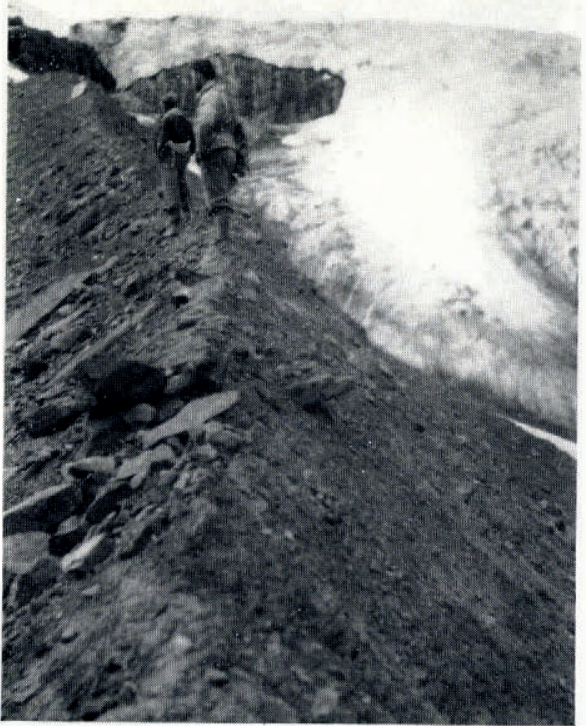

Fig. 4. Summit of morainic arc of Litle fiek'kevarribreen (see R. W. Galloway, $p .730)$ 